\title{
Technopreneurial Intentions: The Effect of Innate Innovativeness and Academic Self-Efficacy
}

\author{
Sa' $^{\prime}$ Ed M. Salhieh ${ }^{1, *}$ and Yousef Al-Abdallat ${ }^{2}$ \\ 1 Faculty of Engineering \& IT, British University in Dubai, Dubai 345015, United Arab Emirates \\ 2 Industrial Engineering Department, School of Engineering, The University of Jordan, Amman 11942, Jordan; \\ abdallat@ju.edu.jo \\ * Correspondence: saed.salhieh@buid.ac.ae
}

Citation: Salhieh, S.M.; Al-Abdallat, Y. Technopreneurial Intentions: The Effect of Innate Innovativeness and Academic Self-Efficacy. Sustainability 2022, 14, 238. https://doi.org/ $10.3390 /$ su14010238

Academic Editor: Andrea Pérez

Received: 14 November 2021

Accepted: 23 December 2021

Published: 27 December 2021

Publisher's Note: MDPI stays neutral with regard to jurisdictional claims in published maps and institutional affiliations.

Copyright: (C) 2021 by the authors. Licensee MDPI, Basel, Switzerland. This article is an open access article distributed under the terms and conditions of the Creative Commons Attribution (CC BY) license (https:/ / creativecommons.org/licenses/by/ $4.0 /)$.

\begin{abstract}
Several factors can affect students' intention to start a new technology-based venture (technopreneurial intentions). Understanding these factors is important when developing technical educational programs. This study investigates the effect of innate innovativeness and academic self-efficacy on technopreneurial self-efficacy and the forming of technopreneurial intentions. It does this by developing a conceptual model that relates technopreneurial intentions, technopreneurial self-efficacy, academic self-efficacy, and innate innovativeness. The data was collected from 378 undergraduate engineering students enrolled in a Jordanian university with a self-administered questionnaire survey. The results of the structural equation modeling (SEM) using AMOS showed that technopreneurial self-efficacy had a positive and significant impact on technopreneurial intentions. Academic self-efficacy had both a direct and indirect positive effect on technopreneurial intention. The indirect effect occurred through increased technopreneurial self-efficacy. Innate innovativeness had a direct effect on technopreneurial intentions, but it did not have a significant indirect effect through technopreneurship self-efficacy as was initially hypothesized. The findings suggest that those who show interest in starting a new technology-based venture have a strong belief in their abilities to perform the technological and entrepreneurial tasks needed, are confident about their ability to acquire the academic technical skills required, and have the inner motivation to seek what is technologically new and different.
\end{abstract}

Keywords: entrepreneurship; technopreneurial intentions; technopreneurial self-efficacy; academic self-efficacy; innate innovativeness

\section{Introduction}

Entrepreneurship is considered a determinant of economic growth and development [1] as it plays a crucial role in the growth of businesses, economies, and nations as the world ventures through the era of the fourth industrial revolution (IE4.0). The world is presented with a magnitude of new technological innovations that can be developed into new ventures. These ventures require the integration of skills from engineering and science in addition to business and entrepreneurial skills [2]. The future of digitalization in the world creates an opportunity for technology-based entrepreneurship or 'technopreneurship' which can be harnessed by engineers.

Engineering education focuses on training future engineers to think logically and follow methodological approaches to uncover solutions that bring value to consumers and society in general [3]. The value creation role played by engineers is the basis of many successful businesses. Thus, engineers can capitalize on business opportunities in engineering and turn them into profitable commercially viable innovations. This means that engineers and engineering education can play an important part in the new economy that is triggered by technology-based innovation. Several educational institutions have realized the importance of preparing engineers for entrepreneurship and designed new "engineering 
entrepreneurship" programs or integrated entrepreneurship instruction into their existing curricula. Preparing students to become engineering entrepreneurs (i.e., technopreneurs) requires that they have the capacity and the willingness to harness, develop, organize and manage business ventures conceived with an engineering idea [4]. In addition, it requires they have the creative mindset and the skills needed for problem-solving that the field of engineering is known for. Several recent studies addressed how engineering entrepreneurship can be implemented. For example, in 2016, Mäkimurto-Koivumaa and Belt [5] developed a framework that emphasizes action-based learning methods at the beginning of a course while introducing explicit business knowledge gradually after field-specific knowledge has been adequately acquired. Additionally, pedagogical models and instructional design choices for facilitating entrepreneurial experiences in engineering education were discussed by Hagvall Svensson et al. in 2020 [6]. While in 2021 Lynch et al. [7] suggested adopting "design thinking" as a teaching approach within entrepreneurship education. These studies show the importance and interest in educating engineers to become entrepreneurs or at least to develop students' intention towards developing technology-based ventures, i.e., developing "technopreneurial intentions".

Educating students in engineering programs to enhance and develop their technopreneurial intentions can have different levels of success. The level of success can be attributed to many factors related to the education program itself and/or to students' characteristics. This paper attempts to investigate whether the success of engineering entrepreneurship education in developing technopreneurial intentions is primarily based on the formal education delivered to students or their personal characteristics. That is, the main research question that this paper aims to answer is: Do technopreneurial intentions result from formal academic education or personal characteristics, or both?

Technopreneurship is a branch of entrepreneurship that describes the process of developing new ventures by combining entrepreneurial skills and technology [8,9]. Entrepreneurship has been defined as the process of creating something new with value [10]. This process includes recognizing opportunities, taking responsibility, exhibiting commitment to a venture, willingness to take calculated risks, and the creative skill to secure the required resources $[10,11]$. The underlying structure of entrepreneurship is the persistent behavior exhibited by individuals or entities and fueled by their determination to create something new with value [12]. The value can be either monetary or a benefit to society. That is, entrepreneurship can be thought of as a dynamic process of vision, change, and creation that requires an application of energy and passion targeted at the creation and implementation of new ideas and creative solutions. Entrepreneurship represents the behavioral characteristics of people or enterprises to perceive, create, and introduce new economic opportunities to the market [13]. Essential ingredients of entrepreneurship include the willingness to take a risk; the ability to formulate an effective venture team; the skill to marshal needed resources; the skill to build a solid business plan; and finally, the vision to recognize an opportunity where others see chaos, contradiction, and confusion [14]. Thus, entrepreneurship is an integrated concept that permeates an individual's enterprise in an innovative manner. It is this mindset that has revolutionized the way business and social ventures are conducted at every level and in every country.

The term "technopreneurs" is used to describe those who merge the strength of technology with the essence of entrepreneurship. A technopreneur is simply an entrepreneur who is tech-savvy and is using technological business opportunities through talent, cash investment, and real-time decision-making skills for the purpose of entrepreneurship [9]. Technopreneurs create new businesses that sell new innovative products and discover high-tech ways to help communities adjust in an ever-changing digital world. Hence, technopreneurs are different from inventors; inventors come up with ideas, but technopreneurs put them into action.

The willingness to start a new technology-based venture is the major characteristic that differentiates a technopreneur from others. A person who possesses such willingness is said to have "technopreneurial intentions" comparable to the entrepreneurial intentions 
possessed by entrepreneurs. Many studies have investigated entrepreneurial intentions and focused on the effect of self-efficacy on entrepreneurial intentions [14-17]. Self-efficacy was defined as "people's judgment of their capabilities to organize and execute courses of action required to attain designated types of performance" [18] and it is a good predictor of entrepreneurial intention $[19,20]$. Several researchers have analyzed technopreneurial intentions among students $[9,21,22]$. This study will investigate the effect of technopreneurial self-efficacy on technopreneurial intentions. The study posits that technopreneurial intentions can be predicted by the perceived belief of individuals in their technological skills allowing them to start a technology-based venture.

Technopreneurial self-efficacy reflects individuals' belief in terms of whether they possess the required technological and entrepreneurial skills needed to start a technologybased venture. Such a belief could be formed as a result of formal education or as a result of personal innate characteristics. This study postulates that technopreneurial selfefficacy and technopreneurial intentions can result from formal academic education or personal characteristics or both. The effect of formal education will be measured through academic self-efficacy (ASE) which addresses students' belief in their own abilities to excel in a certain academic domain. As for the personal characteristics, the study uses innate innovativeness (II) to capture the characteristics required to engage in technopreneurship. That is, people with high innate innovativeness are usually more adept at risk-taking and are more interested in new innovative technologies. Thus, this study suggests that students who exhibit innate innovativeness (II) will develop the intention to start a new technology-based venture.

\section{Theoretical Framework}

This paper investigates the effect of technopreneurial self-efficacy, academic selfefficacy, and innate innovativeness on technopreneurial intentions. Figure 1 displays the relationships between these constructs which are further explained in the following sections.

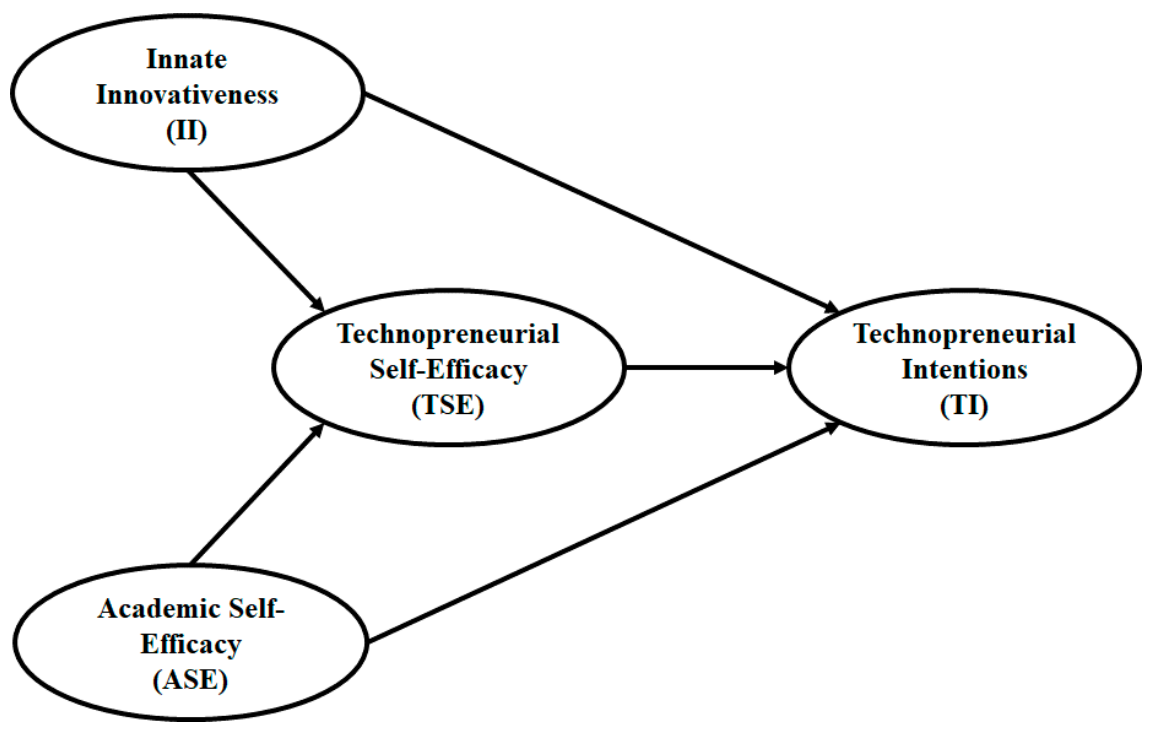

Figure 1. The conceptual model.

\subsection{Technopreneurial Intentions (TI)}

Intentions describe self-predication to engage in a behavior [23], in the sense that once intentions are formed then actual behavior is expected, making intention the single best predictor of actual behavior [24]. Forming entrepreneurial intention is considered a crucial step within the entrepreneurial process as it entails an individual's personal commitment towards creating new ventures [25]. It is considered the best single predictor of actual entrepreneurial actions $[19,20]$. This study investigates the intentions to 
create a new technology-based venture, i.e., the focus will be on individuals' intentions to use science and engineering to pursue business opportunities. Such entrepreneurs are known as "technology entrepreneurs" or technopreneurs [26]. A technopreneur is an entrepreneur who uses technology to create something new for modernization or innovation. So, technopreneurial intentions are a state of mind that direct and guide the actions of the individual toward the development and implementation of new technology business concepts. Technopreneurship intention is a variant of entrepreneurship intention, where the entrepreneurial intention is the intention to start a business at some point in the future [19], while technopreneurship involves starting a technology-based venture. Both involve the belief of a person in his/her determination to start a new business venture and the active planning to do so at some point within their life [25,27]. Accordingly, this study will assess technopreneurial intentions (TI) by adapting the construct used to measure entrepreneurship intentions.

\subsection{Technopreneurial Self-Efficacy (TSE)}

Self-efficacy is defined as "people's judgment of their capabilities to organize and execute courses of action required to attain designated types of performance" [18,28]. Self-efficacy reflects a person's conscious belief in his/her ability and skill to perform a particular task. This belief comes from four sources of information [29]: mastery experience, verbal persuasion, vicarious feedback, and psychological feedback. Mastery experience refers to the impact of previous success in approaching similar tasks. Verbal persuasion refers to the positive or negative feedback received from others that positively or negatively affects individual self-efficacy. Vicarious feedback addresses the influence of role models on self-efficacy. Psychological feedback relates the psychological reaction an individual experiences when facing certain tasks to self-efficacy. Bandura [18] argued that the most important of these is mastery experience since an individual will reflect on and evaluate their performance before engaging in a new endeavor.

People are more inclined to perform tasks if they believe they have high self-efficacy, while they tend to avoid tasks if they believe they have low self-efficacy [29,30]. The term "entrepreneurial self-efficacy" was used by scholars to address self-efficacy within an entrepreneurial context and was defined as "a construct that measures a person's belief in their own abilities to perform on the various skill requirements necessary to pursue a new venture opportunity" [31]. Therefore, entrepreneurial self-efficacy has a mediating role in the development of entrepreneurial intentions [17].

This study investigates the intentions to start a new technology-based venture and uses entrepreneurial self-efficacy to describe technopreneurs' belief in their abilities to start a new technology-based venture; that is a technopreneur must have solid self-reliance in their talents to initiate a new technology venture as well as high self-efficacy to deal with any resistance from society [32]. Thus, the entrepreneurial self-efficacy construct will be adapted to represent technopreneurs' discernment about their ability to perform entrepreneurial tasks in a technology-oriented context and will be called technopreneurial self-efficacy (TSE). Additionally, the study will rely on modifying the entrepreneurial self-efficacy model used by previous studies to account for the self-efficacy to start a new technology-based venture. A hypothesis is articulated to examine the relationship between technopreneurial self-efficacy and technopreneurial intentions and it is projected that:

Hypothesis 1 (H1). Technopreneurial self-efficacy (TSE) has a positive and significant effect on technopreneurial intentions (TI) (i.e., TSE $\rightarrow$ TI).

\subsection{Academic Self-Efficacy (ASE)}

Academic self-efficacy is a person's perception about their capabilities to succeed in a certain academic domain [33]. It refers to learners' judgment about their ability to successfully attain educational goals [34]. Research addressing academic self-efficacy has shown that students who possess a strong sense of academic self-efficacy exhibit a stronger 
commitment to their goals and view difficult tasks as challenges to be mastered rather than threats to be avoided [35]. High efficacious students recover more quickly from failures and setbacks; they attribute failures to a lack of effort or knowledge and show a persistent determination to rectify future efforts to ensure success [36], and they experience less stress while doing so [37]. Students with high academic self-efficacy possess good time management skills and can manage and plan their time effectively. They are better at using their knowledge and skills, in addition to being capable of monitoring, evaluating, and regulating their efforts effectively $[36,38]$. These qualities make them good candidates to become successful entrepreneurs, and it could be hypothesized that students with high academic self-efficacy are more inclined to exhibit entrepreneurial intentions. Accordingly, the second hypothesis to be tested is as follows:

Hypothesis 2 (H2). Academic self-efficacy (ASE) has a direct positive and significant effect on technopreneurial intentions (TI) (i.e., $A S E \rightarrow T I$ ).

Since academic self-efficacy enhances the mastery of education [33], it could also lead to enhancing the mastery of technical skills as presented within engineering and science education. Such mastery would lower learners' technological dexterity leading to an increase in their technopreneurial self-efficacy and, by extension, result in developing technopreneurial intentions. That is, students in engineering and science with high academic self-efficacy would have gained considerable technical knowledge and skills that enhance their self-confidence in using new technology and this would enhance and improve their technopreneurial self-efficacy leading to the formation of technopreneurial intention. Thus, this study will test for the indirect effect that academic self-efficacy has on technopreneurial intentions through technopreneurial self-efficacy. The corresponding hypothesis is:

Hypothesis 3 (H3). Academic self-efficacy (ASE) has an indirect positive and significant effect on technopreneurial intentions (TI) through technopreneurial self-efficacy (TSE) (i.e., ASE $\rightarrow$ TSE $\rightarrow T I)$.

\subsection{Innate Innovativeness (II)}

Innovativeness was defined as the degree to which an individual is receptive to new ideas [39] and describes reactions to the new and different [40]. These reactions can range from a very positive attitude to a very negative attitude towards change [41]. Innovativeness within the context of new product development is called "consumer innovativeness" and represents the tendency of some customers to buy new innovative products instead of sticking to previous ones [42]. Three types of consumer innovativeness exist [43]: (1) innate innovativeness which is considered a general personality trait, (2) domain-specific innovativeness focusing on a product category, and (3) actualized innovative behavior which is related to early adoption ahead of others. Innate innovativeness is believed to be a personality trait that exists alongside other personality traits such as conformity, risk-taking, or tolerance, and it is not likely to be invariant over the individual's lifetime [40]. Innate innovativeness is considered global innovativeness and is distinguished from domain-specific innovativeness that applies to a specific product category [41]. The characteristics of an individual with high innate innovativeness include being a risk-taker who is willing to do things differently, the ability to handle multiple ideas simultaneously, offering different perspectives on old problems, the capability of finding solutions when challenged, standing out in disagreement with a group, being able to inspire and motivate others, and drawing energy from frequent change [43]. These characteristics could stimulate an individual to pursue a career in creating new technological ventures; thus, this study intends to test the impact of innate innovativeness on generating a technopreneurial intention with the following hypothesis: 
Hypothesis 4 (H4). Innate innovativeness (II) has a direct positive and significant effect on technopreneurial intentions (TI) (i.e., II $\rightarrow$ TI).

Additionally, this study suggests that students with high innate innovativeness might be more receptive to engineering and science education allowing them to develop higher technopreneurial self-efficacy and subsequently form technopreneurial intentions. This will be tested by examining the indirect effect that innate innovativeness has on technopreneurial intentions through enhancing technopreneurial self-efficacy. Therefore, it is projected that:

Hypothesis 5 (H5). Innate innovativeness (II) has an indirect positive and significant effect on technopreneurial intentions (TI) through technopreneurial self-efficacy (TSE) (i.e., II $\rightarrow$ TSE $\rightarrow$ TI).

\section{Research Method}

\subsection{Questionnaire}

A questionnaire was developed based on previous research using a five-point Likert scale for each construct. All measurement items have been used in previous research and some were modified to suit the current study. The questionnaire is given in Appendix A. The seven items used to measure the construct technopreneurial intentions (TI) were adapted and customized from the work of Ojiaku, Nkamnebe, and Nwaizugbo, 2018 [44]. The construct "technopreneurial self-efficacy" (TSE) was measured using five items adapted from Doanh and Bernat, 2019 [45]. The "innate innovativeness" (II) construct was measured using ten items adapted from the work of Goldsmith, Freiden, and Eastman 1995; Pallister and Foxall, 1998 [46,47]. The "academic self-efficacy" (ASE) construct was measured using six items adapted from Zander et al. 2018 [48].

\subsection{Participants $\mathcal{E}$ Data Collection}

The participants in this study were all senior full-time students enrolled in seven engineering programs at the University of Jordan: industrial, mechanical, electrical, computer, chemical, civil, and chemical engineering. The self-administered survey was distributed to a total of 490 students (70 from each program who have completed a course in entrepreneurship and innovation). The students were handed the survey and were asked to return it to a mailbox located in the college of engineering to ensure that all students participated voluntarily. A total of 426 surveys were returned, and 48 were considered unusable due to missing data (more than $10 \%$ of the questions were not answered). The final data set contained the responses of 378 students from all programs distributed as shown in Table 1.

Table 1. Sample description.

\begin{tabular}{|c|c|c|}
\hline & Count & $\%$ \\
\hline \multicolumn{3}{|l|}{ Gender: } \\
\hline Male & 246 & $65 \%$ \\
\hline Female & 132 & $35 \%$ \\
\hline \multicolumn{3}{|l|}{ Engineering Major: } \\
\hline Industrial & 53 & $14.02 \%$ \\
\hline Mechanical & 56 & $14.81 \%$ \\
\hline Electrical & 51 & $13.49 \%$ \\
\hline Computer & 54 & $14.29 \%$ \\
\hline Chemical & 55 & $14.55 \%$ \\
\hline Civil & 57 & $15.08 \%$ \\
\hline Chemical & 52 & $13.76 \%$ \\
\hline Total & 378 & \\
\hline
\end{tabular}




\subsection{Data Analysis}

\subsubsection{Measurement Model Analysis}

The measurement model should be evaluated to guarantee scale uni-dimensionality, validity, and reliability before executing the structural equation modeling procedure [9]. Uni-dimensionality is satisfied when factors loading for the items are positive with a minimum value of 0.6. Discriminant validity is met when the constructs are not highly correlated, while convergent validity is met when the value of the average variance extracted (AVE) exceeds the minimum value of 0.5 . The construct reliability is achieved when the values of composite reliability (CR) and average variance extracted (AVE) are at least 0.6 and 0.5 respectively. Finally, the item's internal reliability is considered satisfactory when the value of Cronbach's alpha exceeds 0.7 .

Factor loading values for the items in addition to the Cronbach alpha, CR, and AVE constructs are shown in Table 2. Only two questions ("I am challenged by unanswered questions" and "I often find myself skeptical of new ideas") failed to load at an acceptable level and were dropped from further analysis. The Cronbach's alpha scores and composite reliability coefficients of the constructs exceeded the minimum value of 0.7 which indicates that the items within each variable exhibit high internal consistency and high reproducibility of the findings. Thus, it can be concluded that all latent constructs (TI, TSE, II, and ASE) have achieved convergent validity, construct reliability, and internal reliability.

Table 2. Results for the measurement model.

\begin{tabular}{|c|c|c|c|c|}
\hline Construct, Item & $\begin{array}{l}\text { Factor } \\
\text { Loading }\end{array}$ & $\begin{array}{c}\text { Cronbach's } \\
\text { Alpha }\end{array}$ & $\begin{array}{l}\text { Composite } \\
\text { Reliability }\end{array}$ & $\begin{array}{c}\text { Average } \\
\text { Variance } \\
\text { Extracted }\end{array}$ \\
\hline TI: Technopreneurial Intentions & & 0.935 & 0.937 & 0.684 \\
\hline TI1 & 0.633 & & & \\
\hline TI2 & 0.841 & & & \\
\hline TI3 & 0.942 & & & \\
\hline TI4 & 0.904 & & & \\
\hline TI5 & 0.938 & & & \\
\hline TI6 & 0.786 & & & \\
\hline TI7 & 0.793 & & & \\
\hline TSE: Technopreneurial Self-Efficacy & & 0.939 & 0.940 & 0.758 \\
\hline TSE1 & 0.841 & & & \\
\hline TSE2 & 0.943 & & & \\
\hline TSE3 & 0.904 & & & \\
\hline TSE4 & 0.920 & & & \\
\hline TSE5 & 0.824 & & & \\
\hline II: Innate Innovativeness & & 0.928 & 0.929 & 0.621 \\
\hline II1 & 0.759 & & & \\
\hline II2 & 0.806 & & & \\
\hline II3 & 0.781 & & & \\
\hline II 4 & 0.831 & & & \\
\hline II5 & 0.797 & & & \\
\hline II6 & 0.823 & & & \\
\hline II7 & 0.838 & & & \\
\hline II8 & 0.883 & & & \\
\hline II9 & 0.006 & & & \\
\hline II10 & 0.045 & & & \\
\hline
\end{tabular}


Table 2. Cont.

\begin{tabular}{ccccc}
\hline Construct, Item & $\begin{array}{c}\text { Factor } \\
\text { Loading }\end{array}$ & $\begin{array}{c}\text { Cronbach's } \\
\text { Alpha }\end{array}$ & $\begin{array}{c}\text { Composite } \\
\text { Reliability }\end{array}$ & $\begin{array}{c}\text { Average } \\
\text { Variance } \\
\text { Extracted }\end{array}$ \\
\hline ASE: Academic Self-Efficacy & & 0.915 & 0.915 & 0.646 \\
\hline ASE1 & 0.697 & & & \\
ASE2 & 0.833 & & \\
ASE3 & 0.887 & & \\
ASE4 & 0.879 & & \\
ASE5 & 0.916 & & \\
ASE6 & 0.804 & & \\
\hline
\end{tabular}

The discriminant validity can be assessed through the discriminant validity index summary as shown in Table 3. The diagonal value is the square root of AVE for the respective constructs, while the other values are the correlation between constructs. The discriminant validity of the constructs is achieved when the diagonal values are greater than any values in their rows and columns, respectively [49]. Table 3 shows that the diagonal values are greater than the values in their rows which indicates that the model achieves discriminant validity.

Table 3. Discriminant validity index summary.

\begin{tabular}{ccccc}
\hline & II & TI & ASE & TSE \\
\hline II & $\mathbf{0 . 7 8 8}$ & & & \\
TI & 0.370 & $\mathbf{0 . 8 2 7}$ & & \\
ASE & 0.495 & 0.466 & $\mathbf{0 . 8 0 4}$ & \\
TSE & 0.250 & 0.607 & 0.368 & $\mathbf{0 . 8 7 1}$ \\
\hline
\end{tabular}

\subsubsection{Structural Model Analysis}

A covariance-based structural equation model (SEM) was created using AMOS $^{\circledR}$. Structural equations are used to model relationships among several variables that can be either directly observed or unobserved variables [50]. AMOS calculates several model-fit indices such as the incremental fit index (IFI), relative fit index (RFI), the normed fit index (NFI), the non-normed fit index (NNFI or TLI), the comparative fit index (CFI), the rootmean-square residual index (RMSR), and the root-mean-square error of approximation index (RMSEA). The recommended value for each index $[49,50]$ along with the values obtained for the model under study are shown in Table 4, which indicates that the model applied is acceptable.

Table 4. Model fit indices.

\begin{tabular}{ccc}
\hline Index & Value Obtained & Recommended Values \\
\hline IFI & 0.949 & $\geq 0.90$ \\
RFI & 0.900 & $\geq 0.90$ \\
CFI & 0.949 & $\geq 0.90$ \\
NFI & 0.910 & $\geq 0.90$ \\
NNFI (TLI) & 0.943 & $\geq 0.90$ \\
RMSR & 0.100 & $\leq 0.11$ \\
RMSEA & 0.061 & $<0.10$ \\
\hline
\end{tabular}

The research model along with the path coefficients that represent the direct effects are shown in Figure 2. As for the indirect effects, these was tested using the percentile bootstrap confidence interval. The direct and indirect effects along with the corresponding two-tail bootstrapping $\mathrm{p}$-value are shown in Table 5 . The results show that hypotheses H1, $\mathrm{H} 2, \mathrm{H} 3$, and $\mathrm{H} 4$ are supported while $\mathrm{H} 5$ is rejected. 


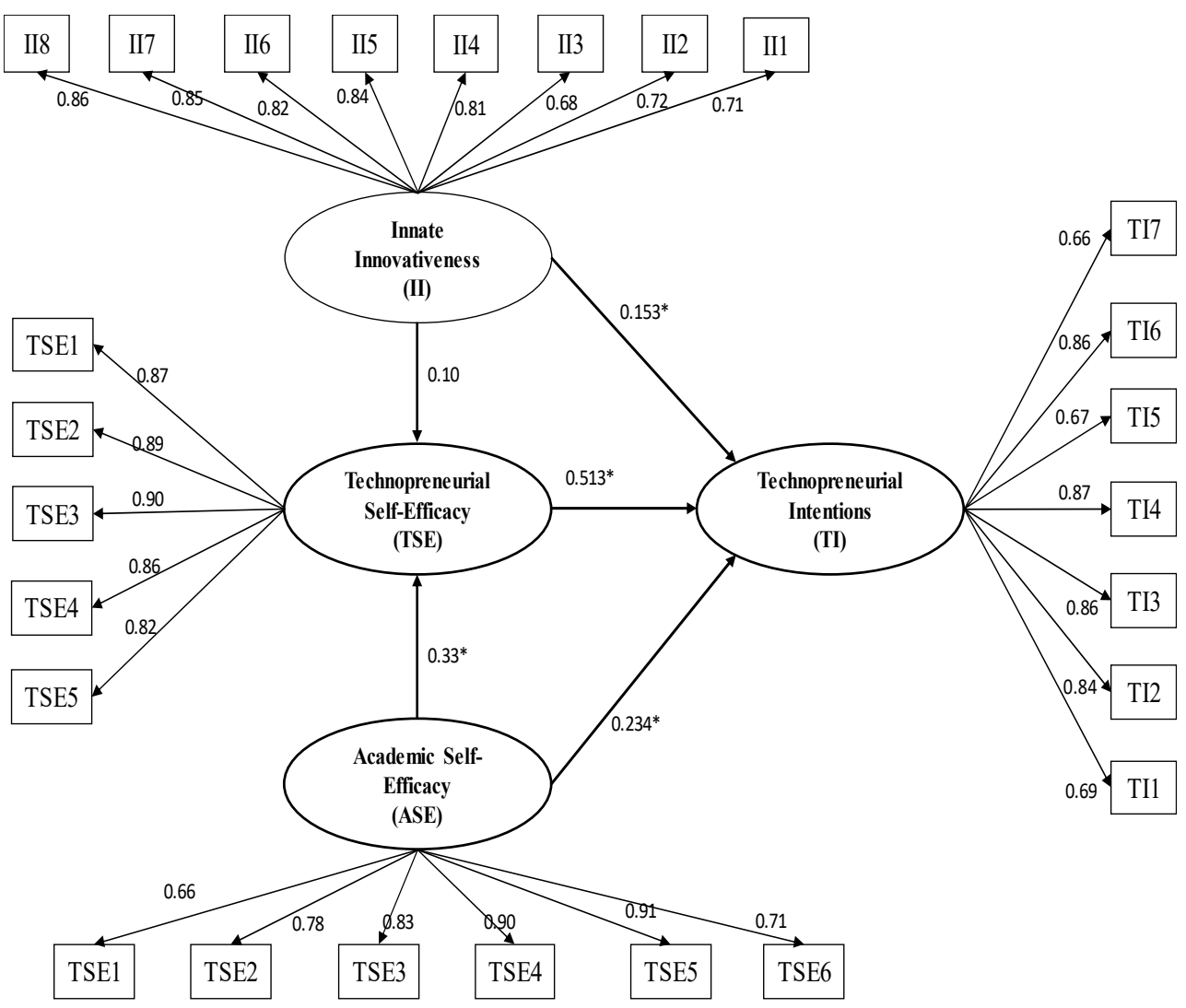

Figure 2. The research model with path coefficients. ( ${ }^{*}$ Significant at $\alpha=5 \%$ ).

Table 5. Results summary.

\begin{tabular}{cccc}
\hline Hypothesis & Model & $\begin{array}{c}\text { Std. Regression } \\
\text { Coef. }\end{array}$ & $\begin{array}{c}\text { Two-Tailed Significance Level } \\
\boldsymbol{p} \text {-Value }\end{array}$ \\
\hline H1 & TSE $\rightarrow$ TI & $0.513^{*}$ & 0.012 \\
H2 & ASE $\rightarrow$ TI & $0.234^{*}$ & 0.001 \\
H3 & ASE $\rightarrow$ TSE $\rightarrow$ TI & $0.168^{*}$ & 0.001 \\
H4 & II $\rightarrow$ TI & $0.153^{*}$ & 0.012 \\
H5 & II $\rightarrow$ TSE $\rightarrow$ TI & 0.053 & 0.135 \\
\hline
\end{tabular}

* Significant at $\alpha=5 \%$.

Hypothesis (H1) which assumed that technopreneurial self-efficacy has a positive and significant effect on technopreneurial intentions is supported with a standardized regression coefficient of 0.513 . This confirms the notion that technopreneurial intentions can be predicted by technopreneurial self-efficacy.

The hypothesis (H2) that academic self-efficacy has a direct and significant effect on technopreneurial intentions is also supported with a standardized regression coefficient of 0.234 . This shows that engineering students who have a strong belief in their academic abilities are more likely to engage in technopreneurial activities. It should be noted here that the value of the regression coefficient implies that other factors might be involved in the relationship which is addressed in $\mathrm{H} 3$. Hypothesis (H3) which tested for the indirect effect that academic self-efficacy (ASE) might have on technopreneurial intentions through technopreneurial self-efficacy is supported. That is, the results show that academic self-efficacy has both a direct effect on technopreneurial intentions and an indirect effect through technopreneurial self-efficacy. This highlights the role of academic self-efficacy in the sense that an engineering student who possesses high academic self-efficacy is more likely to develop high technopreneurial self-efficacy and eventually develop technopreneurial intentions. 
Hypothesis (H4) tested the effect of innate innovativeness on technopreneurial intentions (H4) and it is supported with a standardized regression coefficient of 0.153 . This supports the idea that students who are receptive to new technological ideas are likely to engage in technopreneurial activities. On the other hand, $\mathrm{H} 5$ which tested for the indirect effect that innate innovativeness might have on technopreneurial intention through technopreneurial self-efficacy is not supported; this implies that the innate innovativeness of engineering students did not affect their technopreneurship self-efficacy. Additionally, the results suggest that the effect of innate innovativeness of engineering students, when measured by the standardized regression coefficient, is lower than the effect of academic self-efficacy. This might be an indication that technopreneurship intentions might have been enhanced through the technology-focused education provided to engineering students.

\section{Discussion}

This study investigated the factors affecting technopreneurial intentions. The study posited that technopreneurial intentions could be predicted by technopreneurial selfefficacy. Furthermore, the study postulated that technopreneurial self-efficacy and technopreneurial intentions can be enhanced through formal technical academic education and/or personal characteristics. The effect of formal education was assessed through academic self-efficacy, while personal characteristics were assessed through innate innovativeness. That is, the study suggested that individuals or students who receive technical education and possess strong academic self-efficacy would be more likely to develop technopreneurial intentions. The study also suggested that students who exhibit high innate innovativeness would generate intentions to start a new technology-based venture. Furthermore, the study investigated the effect of academic self-efficacy and innate innovativeness on technopreneurial self-efficacy.

The findings showed that technopreneurial self-efficacy had a positive and significant impact on technopreneurial intentions, thus it can be used as a predictor. This finding is aligned with peer research that addressed the formation of entrepreneurial intentions among engineering students such as [51,52]. As for the effect of academic self-efficacy, the results showed that it had both a direct and indirect positive effect on technopreneurial intention. The indirect effect was manifested by enhancing the technopreneurial selfefficacy. This shows that engineering students who possess high academic self-efficacy are more likely to acquire good technical skills through formal education which will increase their belief in their abilities to start a technology-based venture. It should be noted here that the nature of engineering education can equip students with some qualities that aid in the development of entrepreneurial intentions [53] and provide students with the required skills to address engineering problems within a social context [54].

The results also showed that innate innovativeness had a direct effect on technopreneurial intentions, but it did not have a significant indirect effect through technopreneurship self-efficacy as was initially hypothesized. This might be an indication that individuals with strong innate innovativeness can develop technopreneurial intentions without the need to have high self-confidence in their abilities to develop a technology-based solution on their own. That is, they may resort to seeking help to confront the technical challenges they encounter as opposed to solving them themselves. The validity of this reasoning has not been tested yet and is mainly based on follow-up interviews with some of the respondents. Thus, it could form the basis of future research.

\section{Implications and Further Research}

The findings from this study offer several implications for both technopreneurship research and practice. The significant effect of academic self-efficacy indicates that there could be an "academic path" for technopreneur graduates. This path is fueled by the students' belief in their abilities to learn and absorb the technical education they receive. Thus, it would be of interest to explore how academic self-efficacy could be strengthened among students. Further research could be conducted to analyze the determinants of academic self-efficacy 
and their effect on technopreneurship. Additionally, the nature and the delivery mode of the effect of technological education on academic self-efficacy and technopreneurship could be investigated to identify the best strategies to develop technopreneurs.

The findings related to innate innovativeness showed that it does not affect technopreneurial self-efficacy, while it directly affects technopreneurial intentions. It has been argued in this study that students who possess strong innate innovativeness felt that they had the intention to start a technology-based venture due to their personal interest in new technological innovation; however, they did not have the personal ability to perform the entrepreneurial tasks required to start a technology-oriented venture as was measured by technopreneurial self-efficacy. This finding may sound counter-intuitive and should be further investigated.

This research showed that students with strong academic self-efficacy developed strong technopreneurship self-efficacy and technopreneurial intentions, which signifies the impact and importance of formal academic education on creating technopreneurs who will engage in developing new technology-based ventures. This increases the importance of redesigning current engineering curriculums to strengthen and incorporate an entrepreneurial component into different courses.

\section{Limitations}

Like many other studies, this research is not without limitations. First, the study relied on a convenient sample of students from one university which could limit the generalizability of the findings. The study could be enhanced by including students from several universities to improve the findings' generalizability. Another limitation is that the study used self-reported measures which usually suffer from some bias, since respondents may overstate or understate their perceived abilities when reflecting on their self-efficacy. It should be noted here that the use of such samples and self-reported measures are wellaccepted within the research conducted in this area. For example, the studies conducted on the role of education on entrepreneurial intentions [43,54-57] relied on similar samples and measures.

\section{Conclusions}

Technopreneurship is considered a crucial part of the current digital economy as it enables individuals to launch technology-based ventures. Thus, it is imperative to understand the factors that affect students' intentions to become technopreneurs capable of starting new technology-based ventures. This study showed that students can develop technopreneurial intentions as a result of having: (1) technopreneurial self-efficacy, a strong belief in their abilities to perform the technological and entrepreneurial tasks needed; (2) academic selfefficacy, the confidence in their ability to acquire the academic technical skills required; and (3) innate innovativeness, the inner motivation to seek what is technologically new and different. Furthermore, the study found that academic self-efficacy had an indirect effect on the development of technopreneurial intentions through enhancing the technopreneurial self-efficacy of students, in addition to its direct effect. This suggests that formal academic education has a significant impact on creating future technopreneurs.

Author Contributions: Conceptualization, S.M.S. and Y.A.-A.; methodology, S.M.S. and Y.A.-A.; validation, S.M.S. and Y.A.-A.; formal analysis and investigation, S.M.S. and Y.A.-A.; writing-original draft preparation, S.M.S. and Y.A.-A.; writing-review and editing, S.M.S. and Y.A.-A. All authors have read and agreed to the published version of the manuscript.

Funding: This research received no external funding.

Institutional Review Board Statement: Not applicable.

Informed Consent Statement: Informed consent was obtained from all subjects involved in the study.

Data Availability Statement: Data presented in this study are available on request from the corresponding author. 
Conflicts of Interest: The authors declare no conflict of interest.

\section{Appendix A. Questionnaire}

\begin{tabular}{|c|c|}
\hline \multicolumn{2}{|r|}{ TI: Technopreneurial Intentions } \\
\hline TI1 & A career as a technopreneur (i.e., developing technology-based ventures) is attractive to me. \\
\hline $\mathrm{TI} 2$ & If I had the opportunity and resources, I would like to start a technology-based business. \\
\hline TI3 & People I care about would approve of my intentions to become a technopreneur. \\
\hline TI4 & Most people who are important to me would approve of me becoming a technopreneur. \\
\hline TI5 & Being a technopreneur gives me satisfaction. \\
\hline TI6 & Being a technopreneur implies more advantages than disadvantages to me. \\
\hline TI7 & Amongst various options, I would rather be a technopreneur. \\
\hline \multicolumn{2}{|r|}{ TSE: Technopreneurial Self-Efficacy } \\
\hline TSE1 & I show great aptitude for creativity and innovation. \\
\hline TSE2 & I show great aptitude for leadership and problem-solving. \\
\hline TSE3 & $\begin{array}{l}\text { I can develop and maintain favorable relationships with potential investors interested in } \\
\text { new technology-based innovations. }\end{array}$ \\
\hline TSE4 & I can see new market opportunities for new technology-based products and services. \\
\hline TSE5 & I can develop a working environment that encourages people to try out something new. \\
\hline \multicolumn{2}{|r|}{ II: Innate Innovativeness } \\
\hline II1 & I am generally cautious about accepting new ideas. (r) \\
\hline $\mathrm{II} 2$ & $\begin{array}{l}\text { I rarely trust new ideas until I can see whether the vast majority of people around me } \\
\text { accept them. (r) }\end{array}$ \\
\hline II3 & I am aware that I am usually one of the last people in my group to accept something new. (r) \\
\hline II4 & $\begin{array}{l}\text { I am reluctant about adopting new ways of doing things until I see them working for } \\
\text { people around me, }(\mathrm{r}) .\end{array}$ \\
\hline II5 & I find it stimulating to be original in my thinking and behavior. \\
\hline II6 & I tend to feel that the old way of living and doing things is the best way. (r) \\
\hline II7 & I am challenged by ambiguities and unsolved problems. \\
\hline II8 & I must see other people using new innovations before I will consider them. (r) \\
\hline II9 & I am challenged by unanswered questions. \\
\hline II10 & I often find myself skeptical of new ideas. (r) \\
\hline \multicolumn{2}{|r|}{ ASE: Academic Self-Efficacy } \\
\hline ASE1 & $\begin{array}{l}\text { Regarding my studies, I am able to deal with difficult situations and requirements, if I } \\
\text { make an effort. }\end{array}$ \\
\hline ASE2 & I find it easy to understand new content/topics in my studies. \\
\hline ASE3 & $\begin{array}{l}\text { When I am supposed to talk about a difficult subject in front of the seminar group, I think } \\
\text { I can do it. }\end{array}$ \\
\hline ASE4 & Even if I am sick for a longer period of time, I can still achieve a good outcome in my studies. \\
\hline ASE5 & Even if the instructor doubts my competence, I am still sure I will perform well. \\
\hline ASE6 & I am sure that I can still achieve my desired outcome even if I get a bad grade. \\
\hline
\end{tabular}




\section{References}

1. Dutta, N.; Meierrieks, D. Financial Development and Entrepreneurship', International Review of Economics E Finance; Elsevier: Amsterdam, The Netherlands, 2021; Volume 73, pp. 114-126. [CrossRef]

2. Refaat, A.A. The Necessity of Engineering Entrepreneurship Education for Developing Economies. Int. J. Educ. Inf. Technol. 2009, 3, 85-96.

3. Moaveni, S. Engineering Fundamentals. In An Introduction to Engineering, 5th ed.; Cengage Learning: Stamford, CT, USA, 2016.

4. Habash, R. Green engineering. In Innovation, Entrepreneurship and Design; CRC Press: Boca Raton, FL, USA, 2017. [CrossRef]

5. Mäkimurto-Koivumaa, S.; Belt, P. About, for, in or through entrepreneurship in engineering education. Eur. J. Eng. Edu. 2016, 41, 512-529. [CrossRef]

6. Hagvall Svensson, O.; Adawi, T.; Lundqvist, M.; Williams Middleton, K. Entrepreneurial engineering pedagogy: Models, tradeoffs and discourses. Eur. J. Eng. Educ. 2020, 45, 691-710. [CrossRef]

7. Lynch, M.; Kamovich, U.; Longva, K.K.; Steinert, M. Combining technology and entrepreneurial education through design thinking: Students' Reflections on the Learning Process. Technol. Forecast. Soc. Chang. 2021, 164, 119689. [CrossRef]

8. Fowosire, R.A.; Elijah, O.; Fowosire, R. Technopreneurship: A view of technology, innovations and entrepreneurship. Glob. J. Res. Eng. 2017, 17. Available online: https://globaljournals.org/GJRE_Volume17/5-Technopreneurship-A-View-of-Technology.pdf (accessed on 19 October 2021).

9. Hoque, A.S.M.M.; Awang, Z.B.; Siddiqui, B.A. Technopreneurial Intention among University Students of Business Courses in Malaysia: A Structural Equation Modeling. Int. J. Entrep. Small Medium Enterp. 2017, 4, 1-16.

10. Hisrich, R.D.; Peters, M.P.; Sepherd, D.A. Enterprenuership; Mc Graw Hill Education: New York, NY, USA, 2017.

11. Kirby, D.A. Entrepreneurship education: Can business schools meet the challenge? Educ. Train. 2004, 46, 510-519. [CrossRef]

12. Howard, F.; O'Connor, A.; Kuratko, D.F. Entrepreneurship: Theory, Process, Practice, 4th ed.; Cengage Learning: Stamford, CT, USA, 2016.

13. Wennekers, S.; Thurik, R. Wennekers-Thurik1999_Article_LinkingEntrepreneurshipAndEcon. Small Bus. Econ. 1999, 13, 27-55. [CrossRef]

14. Kuratko, D.F. The emergence of entrepreneruship education-Luratko, 2005. Sage Publ. J. 2005, 29, 577-597. Available online: https:/ /journals.sagepub.com/doi/abs/10.1111/j.1540-6520.2005.00099.x?journalCode=etpb (accessed on 19 October 2021).

15. Fernandes, C.; Ferreira, J.J.; Raposo, M.; Sanchez, J.; Hernandez-Sanchez, B. Determinants of entrepreneurial intentions: An international cross-border study. Int. J. Innov. Sci. 2020, 10, 129-142. [CrossRef]

16. Roy, R.; Akhtar, F.; Das, N. Entrepreneurial intention among science \& technology students in India: Extending the theory of planned behavior, International Entrepreneurship and Management Journal. Int. Entrep. Manag. J. 2017, 13, 1013-1041. [CrossRef]

17. Zhao, H.; Hills, G.E.; Seibert, S.E. The mediating role of self-efficacy in the development of entrepreneurial intentions. J. Appl. Psychol. 2005, 90, 1265-1272. [CrossRef]

18. Bandura, A. Self-Efficacy. In The Exercise of Control; W.H. Freeman \& Co.: New York, NY, USA, 1997.

19. Lee, L.; Wong, P.K.; Foo, M.D.; Leung, A. Entrepreneurial intentions. The influence of organizational and individual factors. J. Bus. Ventur. 2011, 26, 124-136. [CrossRef]

20. Thompson, E.R. Entrepreneurial Intent and Development Reliable Metric, Entrepreneurship. Theory Pract. 2009, 33, 669-695. Available online: http:/ / papers.ssrn.com/sol3/papers.cfm?abstract_id=1396451 (accessed on 19 October 2021). [CrossRef]

21. Singhry, H.B. The Effect of Technology Entrepreneurial Capabilities on Technopreneurial Intention of Nascent Graduates. Eur. J. Bus. Manag. 2015, 7, 8-20.

22. Yordanova, D.; Filipe, J.; Coelho, M.P. Technopreneurial Intentions among Bulgarian STEM Students: The Role of University. Sustainability 2020, 12, 6455. [CrossRef]

23. Ajzen, I. The Theory of Planned Behavior. Organ. Behav. Hum. Decis. Process. 1991, 50, 179-211. [CrossRef]

24. Ajzen, I.; Czasch, C.; Flood, M.G. From Intentions to Behavior: Implementation Intention, Commitment, and Conscientiousness. J. Appl. Soc. Psychol. 2009, 39, 1356-1372. [CrossRef]

25. Ozaralli, N.; Rivenburgh, N.K. Entrepreneurial intention: Antecedents to entrepreneurial behavior in the U.S.A. and Turkey. J. Glob. Entrep. Res. 2016, 6, 1. [CrossRef]

26. Wickham, P.A. Strategic Entrepreneurship. In A Decision Making Approach to New Venture Creation and Management, 2nd ed.; Prentice Hall: London, UK, 1998.

27. Molino, M.; Dolce, V.; Cortese, C.G.; Ghislieri, C. Personality and social support as determinants of entrepreneurial intention. Gender differences in Italy. PLoS ONE 2018, 13, e0199924. [CrossRef]

28. Mauer, R.; Neergaard, H.; Linstad, A.K. Understanding the Entrepreneurial Mind. In Understanding the Entrepreneurial Mind; Springer: New York, NY, USA, 2009. [CrossRef]

29. Newman, A.; Obschonka, M.; Schwarz, S.; Cohen, M.; Nielsen, I. Entrepreneurial self-efficacy: A systematic review of the literature on its theoretical foundations, measurement, antecedents, and outcomes, and an agenda for future research. J. Vocat. Behav. 2019, 110, 403-419. [CrossRef]

30. McGee, J.E.; Peterson, M.; Mueller, S.L.; Sequeira, J.M. Entrepreneurial Self-Efficacy: Refining the Measure. Entrep. Theory Pract. 2009, 33, 965-988. [CrossRef]

31. De Noble, A.; Jung, D.; Ehrlich, S. Entrepreneurial self efficacy. In The Development of a Measure and Its Relationship to Entrepreneurial Action, in Frontiers of Entrepreneurship Research; Babson College: Babson Park, MA, USA, 1999; pp. $73-87$. 
32. Urban, B. A gender perspective on career preferences and entrepreneurial self-efficacy. SA J. Hum. Resour. Manag. 2010, 8, 1-8. [CrossRef]

33. Honicke, T.; Broadbent, J. The influence of academic self-efficacy on academic performance: A systematic review. Educ. Res. Rev. 2016, 17, 63-84. [CrossRef]

34. Elias, S.M.; MacDonald, S. Using Past Performance, Proxy Efficacy, and Academic Self-Efficacy to Predict College Performance. J. Appl. Soc. Psychol. 2007, 37, 2518-2531. [CrossRef]

35. Chemers, M.M.; Hu, L.-T.; Garcia, B.F. Academic self-efficacy and first year college student performance and adjustment. J. Educ. Psychol. 2001, 93, 55-64. [CrossRef]

36. Pajares, F.; Schunk, D. Self-beliefs in psychology and education. In An Historical Perspective; Aronson, J., Ed.; Improving Academic Achievement; Academic Press: New York, NY, USA, 2002; pp. 3-21.

37. Solberg, V.S.; Gusavac, N.; Hamann, T.; Felch, J.; Johnson, J.; Lamborn, S.; Torres, J. The Adaptive Success Identity Plan (ASIP): A Career Intervention for College Students. Career Dev. Q. 1998, 47, 48-95. [CrossRef]

38. Fenollar, P.; Román, S.; Cuestas, P.J. University students' academic performance: An integrative conceptual framework and empirical analysis. Br. J. Educ. Psychol. 2007, 77, 873-891. [CrossRef]

39. Midgley, D.F.; Dowling, G.R. Innovativeness: The Concept and Its Measurement. J. Consum. Res. 1978, 4, 229-242. [CrossRef]

40. Hirschman, E.C. Innovativeness, Novelty Seeking, and Consumer Creativity. J. Consum. Res. 1980, 7, 283-295. [CrossRef]

41. Goldsmith, R.E.; Foxall, G.R. The Measurement of Innovativeness. Int. Handb. Innov. 2003, 5, 321-330. [CrossRef]

42. Steenkamp, J.-B.E.M.; Ter Hofstede, F.; Wedel, M. A Cross-National Investigation into the Individual and National Cultural Antecedents of Consumer Innovativeness. J. Mark. 1999, 63, 55. [CrossRef]

43. Im, S.; Mason, C.H.; Houston, M.B. Does innate consumer innovativeness relate to new product/service adoption behavior? The intervening role of social learning via vicarious innovativeness. J. Acad. Mark. Sci. 2007, 35, 63-75. [CrossRef]

44. Ojiaku, O.C.; Nkamnebe, A.D.; Nwaizugbo, I.C. Determinants of entrepreneurial intentions among young graduates: Perspectives of push-pull-mooring model. J. Glob. Entrep. Res. 2018, 8, 24. [CrossRef]

45. Doanh, D.C.; Doanh, D.C.; Bernat, T.; Bernat, T. Entrepreneurial self-efficacy and intention among vietnamese students: A meta-analytic path analysis based on the theory of planned behavior. Procedia Comput. Sci. 2019, 159, 2447-2460. [CrossRef]

46. Goldsmith, R.E.; Freiden, J.B.; Eastman, J. The generality/specificity issue in consumer innovativeness research. Technovation 1995, 15, 601-612. [CrossRef]

47. Hu, L.-T.; Bentler, P.M. Cutoff criteria for fit indexes in covariance structure analysis: Conventional criteria versus new alternatives Struct. Equ. Modeling A Multidiscip. J. 1999, 6, 1-55. [CrossRef]

48. Byrne, B.M. Structural equation modeling with AMOS, EQS, and LISREL: Comparative approaches to testing for the factorial validity of a measuring instrument. Int. J. Test. 2001, 1, 55-86. [CrossRef]

49. Pallister, J.G.; Foxall, G.R. Psychometric properties of the Hurt-Joseph-Cook scales for the measurement of innovativeness. Technovation 1998, 18, 663-675. [CrossRef]

50. Zander, L.; Brouwer, J.; Jansen, E.; Crayen, C.; Hannover, B. Academic self-efficacy, growth mindsets, and university students' integration in academic and social support networks. Learn. Individ. Differ. 2018, 62, 98-107. [CrossRef]

51. Yi, S.; Duval-Couetil, N. What Drives Engineering Students To Be Entrepreneurs? Evidence of Validity for an Entrepreneurial Motivation Scale. J. Eng. Educ. 2018, 107, 291-317. [CrossRef]

52. Gilmartin, S.K.; Thompson, M.E.; Morton, E.; Jin, Q.; Chen, H.L.; Colby, A.; Sheppard, S.D. Entrepreneurial intent of engineering and business undergraduate students. J. Eng. Educ. 2019, 108, 316-336. [CrossRef]

53. Cui, J.; Sun, J.; Bell, R. The impact of entrepreneurship education on the entrepreneurial mindset of college students in China: The mediating role of inspiration and the role of educational attributes. Int. J. Manag. Educ. 2019, 19, 100296. [CrossRef]

54. Dabbagh, N.; Menascé, D.A. Student Perceptions of Engineering Entrepreneurship: An Exploratory Study. J. Eng. Educ. 2006, 95, 153-164. [CrossRef]

55. Heuer, A.; Kolvereid, L. Education in entrepreneurship and the Theory of Planned Behaviour. Eur. J. Train. Dev. 2014, 38, 506-523. [CrossRef]

56. Jena, R. Measuring the impact of business management Student's attitude towards entrepreneurship education on entrepreneurial intention: A case study. Comput. Hum. Behav. 2020, 107, 106275. [CrossRef]

57. Karlsson, T.; Moberg, K. Improving perceived entrepreneurial abilities through education: Exploratory testing of an entrepreneurial self efficacy scale in a pre-post setting. Int. J. Manag. Educ. 2012, 11, 1-11. [CrossRef] 